\title{
AN EXPECTED DECREASE IN INCIDENCE OF WILSON'S DISEASE DUE TO DECREASE IN CONSANGUINITY
}

\author{
Tomohiro SAITo \\ Department of Public Health, School of Nursing and Medical Technology, \\ University of Occupational and Environmental Health, \\ Yahatanishi-ku, Kitakyushu, Fukuoka 807, Japan
}

\begin{abstract}
Summary An expected decrease in incidence of Wilson's disease due to recent decrease in consanguinity rate in the population was assessed based on 162 affected families collected in Japan. The estimated gene frequency was 0.0055 and the corresponding incidence of the disease in the period from 1945 to 1965 was around 1 in 20,000. This incidence is expected to have decreased to 1 in 30,000 in the early 1980s due to decreased consanguinity rate which is supposedly less than $1 \%$ in Japan. The proportion of patients from consanguineous marriage among all the patients is also expected to have decreased from around $40 \%$ to a little less than $10 \%$ during the same period.
\end{abstract}

\section{INTRODUCTION}

Incidence of a genetic disease under autosomal recessive inheritance is greatly influenced by the consanguinity rate in the population. Due to decrease in consanguinity in various countries over the past decades (Stern, 1973), incidence of autosomal recessive disease is expected to have decreased. However, the magnitude of the expected change in such genetic disease, in spite of the general recognition of the notion, has not well been reported. The purpose of this report is to estimate the magnitude of the change in the incidence of Wilson's disease (hepatolenticular degeneration), which is autosomal recessive, based on epidemiological data collected in Japan where the consanguinity rate has been rapidly decreasing (Imaizumi et al., 1975).

\section{SOURCE OF DATA}

Two hundred and eighty-nine families with at least one case of Wilson's disease were collected through mail questionnaires sent to all medical school hospitals and to the hospitals from which cases have been reported in medical journals or academic

Received May 7, 1985 ; revised version received August 26, 1985 
meetings (Saito, 1981). The majority of cases were born between 1945 and 1965 . Of these collected families complete information on the following were obtained from 162 families: consanguinity of the parents, the number of siblings, age and health status of each member of the family including presence or absence of Wilson's disease, and if death has occurred, the cause and age of death. These 162 families were used for the following analysis.

\section{METHOD}

The gene frequency of Wilson's disease was estimated first by the extended Dahlberg's formula $(\mathrm{Li}, 1976 \mathrm{a}), \mathrm{q}=\frac{\mathrm{c} / 16-\mathrm{kF}}{(\mathrm{k}-\mathrm{c})+(\mathrm{c} / 16-\mathrm{kF})}$, whereby $\mathrm{q}$ is the gene frequency in the population to be estimated, $\mathrm{c}$ is the proportion of first-cousin marriages in the population, $\mathrm{F}$ is the coefficient of inbreeding in the population, and $\mathrm{k}$ is the proportion of recessive homozygotes (the affected) from first-cousin marriages to those from all marriages. The value for $\mathrm{k}$ was estimated to be 0.3245 from the collected data. The majority of cases were born between 1945 and 1965 and the years of marriage of the parents were, on the average, 7 years earlier. Therefore the value for $c$ during the relevant period was taken to be from 0.040 to 0.045 and the corresponding value for $F$ from 0.0031 to 0.0035 judging from published data (Imaizumi et al., 1975; Schull and Neel, 1965). Thus, the gene frequency was estimated to be between 0.00522 and 0.00596 and a value of 0.0055 was used for the following analysis.

When $F$ is larger than 0.001 and changes drastically, the gene frequency also changes. The difference in gene frequency between the old and new equilibrium would be substantial. But such a change takes place gradually and slowly over more than a few decades (Cavalli-Sforza and Bodmer, 1971). Therefore, the gene frequency was assumed to be constant through the 1940s to the 1980s in this analysis.

By this assumption the change in the genotype frequency and hence the change in the incidence due to change in consanguinity rate was calculated using the formulae $q^{2}(1-F)+F q$ for recessive homozygotes and $2 p q(1-F)$ for heterozygotes ( $\left.\mathrm{Li}, 1976 b\right)$. The change in the proportion of the affected children from first-cousin marriages due to change in consanguinity rate was calculated by a formula, $k=\frac{c(1+15 q)}{16\{(1-F) q+F\}}$ which is algebraic rearrangement of the extended Dahlberg's formula.

\section{RESULTS}

Table 1 shows an estimated change in genotype frequency and hence the incidence of Wilson's disease due to change in consanguinity rate. As the value of $\mathrm{c}$ and $\mathrm{F}$ decrease, the incidence also decreases. When $\mathrm{c}$ is $0.5 \%$, the incidence is around 1 in 
30,700 which is about two-thirds of the incidence when $c$ is around $4.3 \%$, the value used in estimating the gene frequency in the present study.

The change in the proportion of the affected children from first-cousin marriages to those from all marriages $(\mathrm{k})$ is shown in Fig. 1. When the proportion of firstcousin marriages in the population, $\mathrm{c}$, is around $4.3 \%, \mathrm{k}$ is 0.3245 which corresponds to the value estimated from the collected data. When the value of $\mathrm{c}$ is between $1 \%$ and $0.5 \%$, which is the assumed value of $\mathrm{c}$ in Japan in the first half of the $1980 \mathrm{~s}, \mathrm{k}$ of Wilson's disease patients is between $10.8 \%$ and $5.7 \%$.

Table 1. Change of genotype frequency due to change in consanguinity rate.

\begin{tabular}{clllllll}
\hline $\mathrm{q}$ & 0.0055 & 0.0055 & 0.0055 & 0.0055 & 0.0055 & 0.0055 & 0.0055 \\
$\mathrm{c}$ & 0.001 & 0.005 & 0.010 & 0.020 & 0.030 & 0.040 & 0.050 \\
$\mathrm{~F}$ & 0.000078 & 0.00044 & 0.00078 & 0.0016 & 0.0023 & 0.0031 & 0.0039 \\
\hline $\mathrm{q}^{2}(1-\mathrm{F})+\mathrm{Fq}\left(\times 10^{-5}\right)$ & 3.07 & 3.26 & 3.45 & 3.90 & 4.28 & 4.72 & 5.16 \\
1 per & 32,600 & 30,700 & 29,000 & 25,600 & 23,400 & 21,200 & 19,400 \\
$2 \mathrm{pq}(1-\mathrm{F})\left(\times 10^{-2}\right)$ & 1.094 & 1.093 & 1.093 & 1.092 & 1.091 & 1.091 & 1.090 \\
1 per & 91 & 91 & 91 & 92 & 92 & 92 & 92
\end{tabular}

$q$, gene frequency; $c$, proportion of first-cousin marriages in the population; $F$, coefficient of inbreeding; $\mathrm{q}^{2}(1-\mathrm{F})+\mathrm{Fq}$, recessive homozygote; $2 \mathrm{pq}(1-\mathrm{F})$, heterozygote.

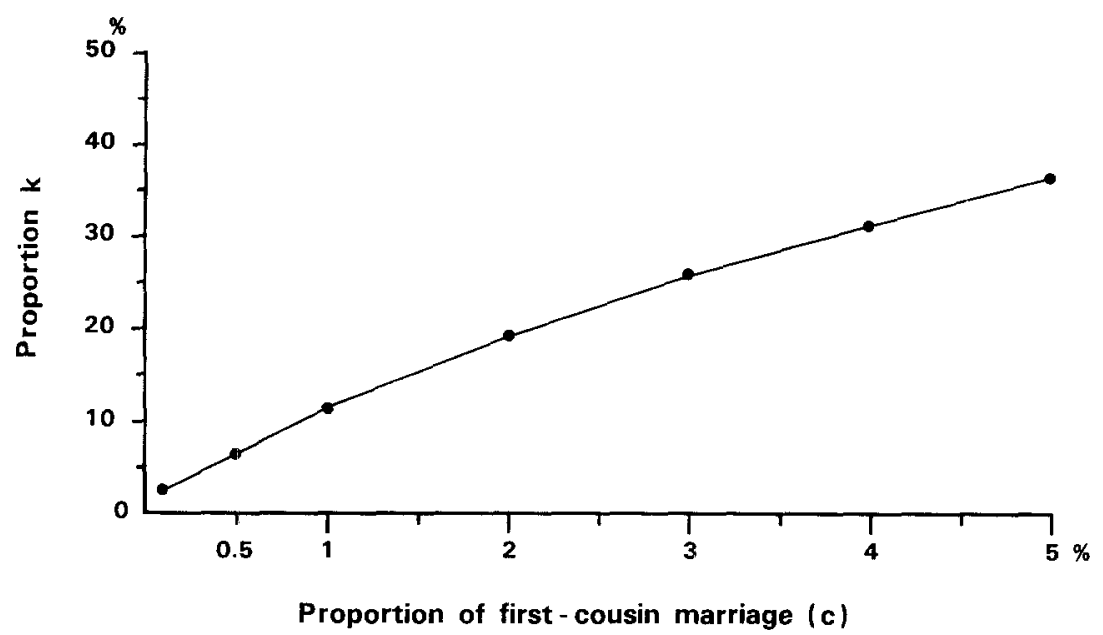

Fig. 1. The proportion of the affected children from first-cousin marriages to those from all marriages at various levels of $\mathrm{c}$ and $\mathrm{F}$ estimated by

$$
\mathrm{k}=\frac{\mathrm{c}(1+15 \mathrm{q})}{16\{(1-\mathrm{F}) \mathrm{q}+\mathrm{F}\}} .
$$




\section{DISCUSSION}

In estimating the gene frequency by the extended Dahlberg's formula in the present study, the terms c, $\mathrm{F}$ and $\mathrm{k}$ were assumed to be constant for the period of 20 years. Actually because of rapid decrease in consanguinity rate, the value of $\mathrm{k}$ has been decreasing in the collected data. However, the estimated gene frequencies did not vary greatly when they were calculated separately in each 5 year period from 1945 to 1965 based on the values for $\mathrm{c}$ and F of published data (Imaizumi et al., 1975) and the value for $k$ of this study. Therefore, the estimated gene frequency of 0.0055 is not unreasonable. It is also quite compatible with an estimated gene frequency from $3.3 \times 10^{-3}$ to $6.6 \times 10^{-3}$ estimated by Arima and Kurumada (1962) based on reported cases in the literature and cases obtained through personal communication in Japan,

The result of this study provides the following findings. Firstly, the decrease in the proportion of patients from consanguineous marriages is almost proportional to the decrease in consanguinity rate in the range of change in the recent decades. Secondly, whereas the patients from consanguineous marriages were nearly $40 \%$ in the 1940 s and $1950 \mathrm{~s}$ in Japan, they are supposedly a little less than $10 \%$ in the first half of the 1980s when c, proportion of first-cousin marriage, in Japan is assumed to be between $0.5 \%$ and $1 \%$ from the result of the study by Imaizumi et al. (1975). Thirdly, higher frequency of Wilson's disease in Japan than in Western countries should not be ascribed to the higher consanguinity rate in Japan, given that assumed disease frequencies in Japan and in Western countries be correct (Walshe, 1984). The assumed disease frequencies in Western countries ranged from 1 in 34,300 to 1 in 4,000,000 (Bearn, 1960; Sternlieb and Scheinberg, 1968; Tschumi et al., 1973; Rigardetto and Trevisio, 1975; Bachman et al., 1979; Danks, 1983). Even when the consanguinity rate has approached those in Western countries, the frequency in Japan extrapolated from the result of this study would be still higher.

Despite the expected decrease in the incidence, Wilson's disease is still quite frequent as compared to other monogenic diseases currently under mass screening in Japan (Wada et al., 1984). The disease is preventable and mass screening should be considered (Saito, 1981).

Acknowledgement I thank Dr. K. Nomiyama at Jichi Medical School for support of this study, Dr. J.A.H. Waterhouse at the University of Birmingham for helpful suggestions and doctors at various hospitals for their co-operation in providing data for the study. Part of the study was done during the author's tenure of a British Council Scholarship at the University of Birmingham and part was supported by a science research grant (grant number 56770316) from the Ministry of Education, Science and Culture of Japan.

\section{REFERENCES}

Arima, M. and Kurumada, T. 1962. Genetical studies of Wilson's disease. II. Mode of inheritance and gene frequency in Japan. Paediatr. Univ. Tokyo 7: 7-12.

Bachman, von H., Lößner, J., and Biesold, D. 1979. Untersuchungen zur Wilsonschen Erkrankung 
in der DDR. Teil I: Genetik und Epidemiologie. Z. Gesamte Inn. Med. 34: 744-748.

Bearn, A.G. 1960. A genetical analysis of thirty families with Wilson's disease (hepatolenticular degeneration). Ann. Hum. Genet. 24: 33-43.

Cavalli-Sforza, L.L. and Bodmer, W.F. 1971. In The Genetics of Human Populations, W.H. Freeman, San Francisco, pp. 352-385.

Danks, D.M. 1983. Disorders of copper metabolism. In Principles and Practice of Medical Genetics, Emery, A.E.H. and Rimoin, D.L., eds., Churchill Livingstone, London, pp. 1319-1328.

Imaizumi, Y., Shinozaki, N., and Aoki, H. 1975. Inbreeding in Japan: results of a nationwide study. Jpn. J. Human Genet. 20: 91-107.

Li, C.C. 1976a. In First Course in Population Genetics, The Boxwood Press, Pacific Grove, California, pp. 358--363.

Li, C.C. 1976b. In First Course in Population Genetics, The Boxwood Press, Pacific Grove, California, pp. 235-238.

Rigardetto, R. and Trevisio, A. 1975. Recenti acquisizioni sulla terapia del morbo di Wilson. Minerva Pediatr. 27: 177-186.

Saito, T. 1981. An assessment of efficiency in potential screening for Wilson's disease. J. Epidemiol. Community Health $35: 274-280$.

Schull, W.J. and Neel, J.V. 1965. Consanguineous marriages in Japan. In The effect of Inbreeding on Japanese Children, Schull, W.J., and Neel, J.V., eds., Harper and Row, New York, pp. 11-30.

Stern, C. 1973. In Principles of Human Genetics, W.H. Freeman, San Francisco, 3rd Ed., pp. 488490.

Sternlieb, I. and Scheinberg, I.H. 1968. Prevention of Wilson's disease in asymptomatic patients. New Engl. J. Med. 278: 352-359.

Tschumi, A., Colombo, J.P., and Moser, H. 1973. Die Wilsonsche Krankheit in der Schweiz. Schweiz. Med. Wschr. 103: 140-145.

Wada, Y., Nakajima, H., Irie, M., Hirayama, M., and Suwa, S. 1984. Newborn mass screening in Japan-1984. Jpn. J. Human Genet. 29: 277-286.

Walshe, J.M. 1984. Wilson's disease. Br. Med. J. 288: 1689. 